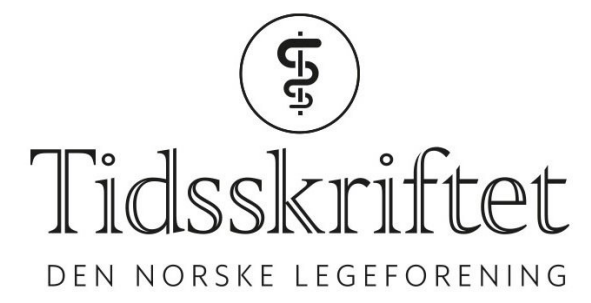

\title{
Kunsten å være seg selv
}

INTERVJU

JANNIKE REYMERT

Bakklandet legekontor

Namsos

Psykiater Tormod Huseby har skrevet bok om hvorfor vi er så redde for å være oss selv og hvordan det styrer handlingene våre.

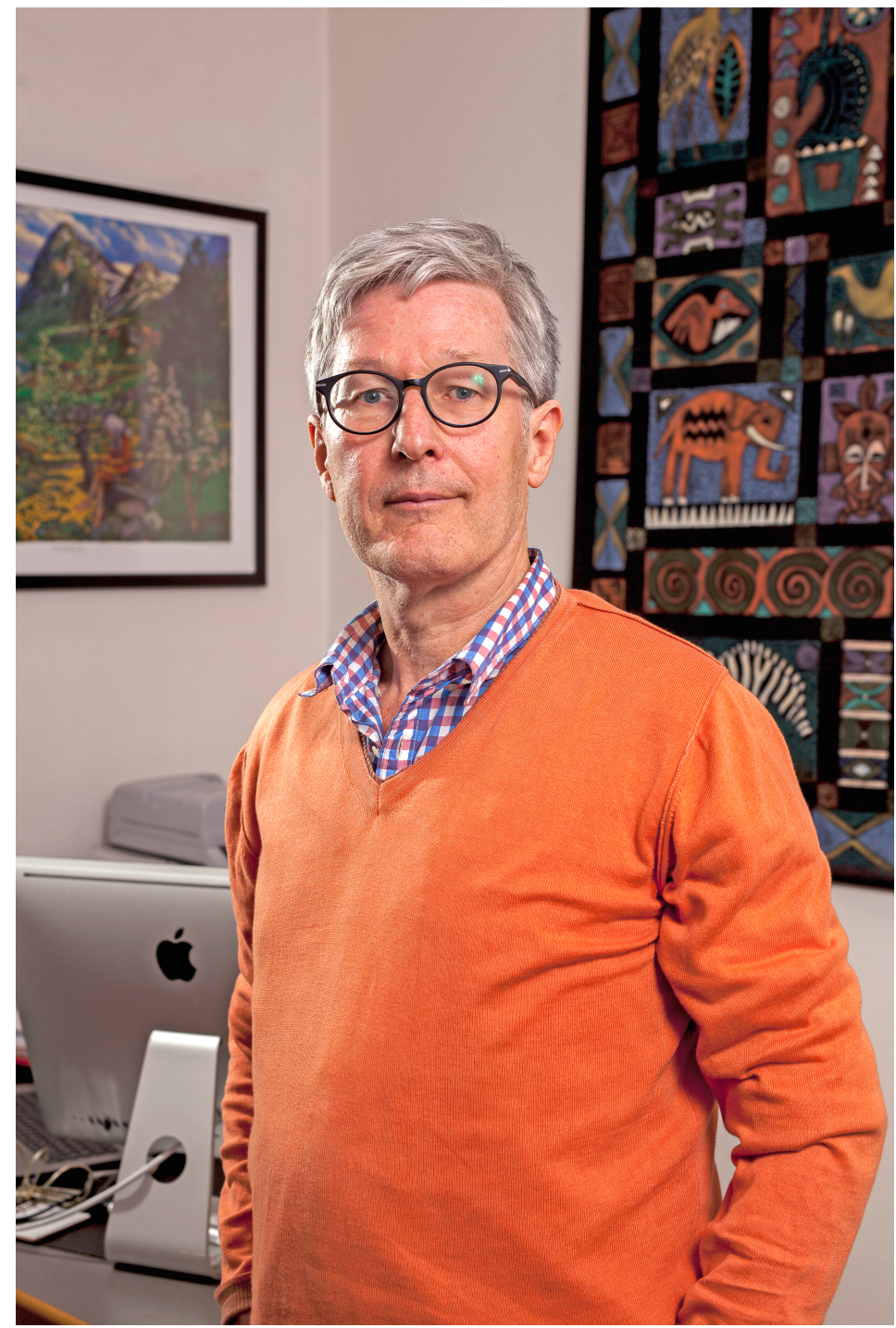

Alle foto: Niklas Lello

I god psykodynamisk tradisjon er han opptatt av at barndommens sår skaper 
uhensiktsmessig atferd og mye lidelse i voksen alder. Med årene har han utviklet en liten vri på sin egen rolle i terapirommet:

- Jeg velger å være åpen med pasientene om det som har vært vanskelig i mitt liv. Da blir relasjonen mellom meg og dem mer likeverdig.

En av historiene han henter fra sitt eget liv er om julen da hans far ble invitert med til hans svigerfamilie på Bygdøy.

- Far var støpebas og hadde syv års folkeskole. Han hadde sin yrkesstolthet. Han sto opp klokken 5 om morgenen og syklet ned til Spikerverket. Han var på alle måter en harmonisk mann. Svigerfar hadde doktorgrad på fransk fra Sorbonne og hadde vært innstilt til Kongen for gode eksamensresultater og svigermor var barnebarn av Elias Blix. I god borgerlig stil fikk vi et glass sherry før maten. Plutselig skjelver jeg sånn på hånden at sherryen bokstavelig talt skvalper i glasset. Skammen jeg følte over skjelvingen var én ting, den største skammen var at jeg åpenbart ikke følte at far var bra nok for den fine svigerfamilien min. Ubevisst hadde jeg gruet meg til dette møtet - fordommen om at han ikke ville klare å representere meg var enorm. Dette handlet også mye om mine fordommer mot borgerskapet.

Det viste seg at svigerforeldrene syntes det var både uproblematisk og hyggelig å treffe sin datters svigerfar. - Jeg skjønte etter hvert at far heller ikke opplevde dette møtet som vanskelig, tvert imot koste han seg hele kvelden. Han lot ikke andres blikk være styrende i sitt liv. Han var ikke redd for å være seg selv, det var jeg som var det.

Tormod Huseby bruker historiene om seg selv for å illustrere at vi alle sliter med de samme problemene, mer eller mindre. - Det jeg forteller mine pasienter, er avklart. Jeg mener jeg mestrer å finne balansen slik at mine problemer ikke tar plass i samtalen. Grensen til det private går på det som ikke kan fortelles videre. Det krever varsomhet, og selvfølgelig gjør jeg feil. Dem lærer jeg av.

\section{Skam}

Tanken bak denne strategien er at hvis han skal få resultater, må han hjelpe pasienten til følelsesmessige forandringer.

\section{Tormod Huseby}

Født 12. mai 1954

- Cand.med. 1981 Universitetet i Oslo

- Spesialist i psykiatri/veileder i psykodynamisk psykoterapi

- Grunnutdanning i kognitiv terapi

- Perioden 1983-2004: Psykiatrisk avdeling, Sentralsykehuset i Rogaland, Dikemark sykehus, Gaustad sykehus og Tøyen DPS

- Privatpraksis i psykiatri i Oslo med fullt driftstilskudd fra 2004

- Har gitt ut flere bøker med psykiske lidelser som tema

- Dersom de opplever meg som fjern og utilnærmelig, skaper det lite trygghet. Pasienter føler ofte sterkt på skammen over å være mindre vellykket enn legen. En psykoterapeut kan i samtalen forstå hvordan de har det og formidle dette. Pasientene kan dermed bli «klokere», men de blir ikke nødvendigvis bedre av å bli forstått. De må eksponere seg for å få til en følelsesmessig forandring. Det er min oppgave å skape så stor trygghet at de tør å komme frem med det mest skambelagte. Skammen må, som andre følelser, erkjennes, 
tolereres og så uttrykkes emosjonelt og kognitivt.

- Hva handler skamfølelser om? De færreste har vel mange dramatiske forhold å skamme seg over?

- Min erfaring er at pasientene er redde for at de er kjedelige, dumme, stygge, rare - kort sagt ikke bra nok. Defekten de føler de har, handler ofte om at de ikke ble bekreftet som seg selv i tidlig alder, at de har vokst opp med krav om å være «a human doer» mer enn «a human being».

- Jeg stusser litt på dette. For hundre år siden ble jo ikke barn sett slik de blir i våre dager. I en stor barneflokk der foreldrene hadde mer enn nok med å få endene til å møtes, måtte barna klare seg med mye mindre oppmerksomhet enn det som er vanlig i dag.

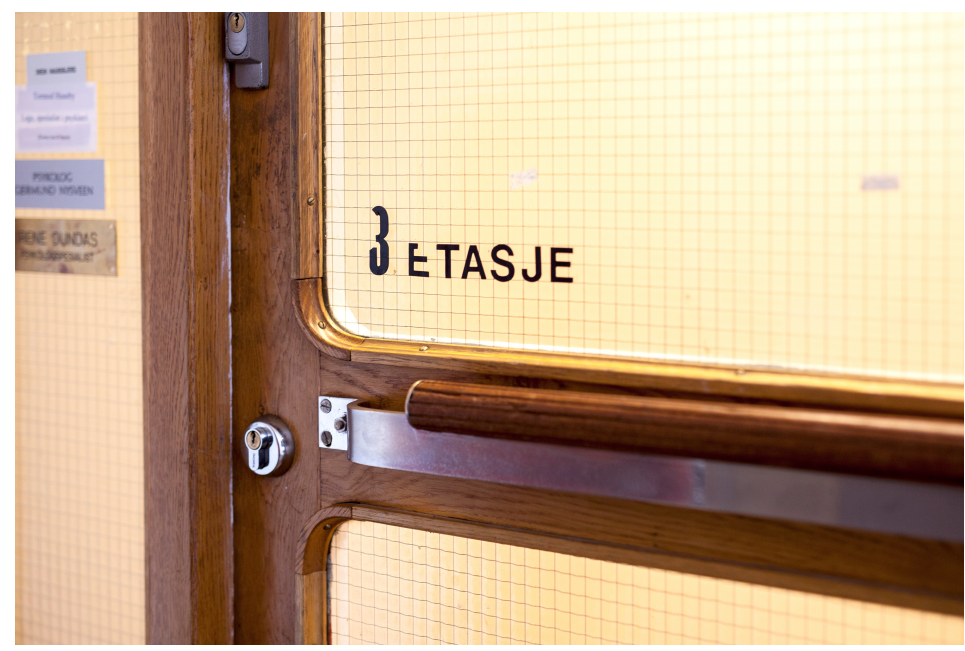

- Skamfølelse har andre uttrykk i vår tid. Før aksepterte man sin plass i samfunnet på en annen måte. Den moderne verden er på mange måter et kappløp mot makt, suksess og materielle goder. I vår tid tør vi ikke være fornøyd med vår egen middelmådighet. Generasjon perfekt føler at de påføres smerte av både foreldre og samfunn når de ikke presterer bra nok - fordi de i for stor grad er blitt sett for hva de presterer, ikke for hvem de er.

\section{Arvesynden}

- Man kan bli litt skremt av det du nå sier. Som foreldre vil vi da alltid lure på om vi klarer å se barna våre godt nok?

- Vi blir jo på en måte aldri sett nok, noen av oss. For mange av mine pasienter har dette vært så dramatisk at de bruker voksenlivet sitt på å bli sett, ofte med lite hensiktsmessige strategier. Det skaper nye problemer i stedet for å lege gamle sår. Det er et begrep som heter "good enough parenting». Alle barn må erfare at de ikke blir sett hele tiden. De må gjennomleve den narsissistiske krenkelsen det medfører, men bare i passe doser. Som foreldre må vi være oss bevisst at barnet må føle en egenverdi og at vi tåler dem også når de ikke søte små engler, men støyende og til dels usympatiske, sier han.

- Jeg jobber i stor grad med pasienter hvis foreldre selv ikke ble sett som barn. De kan la sine barn bli et redskap for deres egen stolthet eller bruke dem som hoggestabbe for defekter de ikke vil eller kan vedkjenne seg. Deres mangelfulle evne til empati overfor barna kan føre til livslange sår. Jeg kaller dette arvesynden. Pasientene som kommer til meg, er ofte redde for å bringe arvesynden videre.

Tormod Huseby forteller at det gjerne kan ta et år før pasienten åpner opp og forteller om det de skammer seg mest over.

- Det er ydmykende å snakke om dette. Tristheten det medfører er vanskelig å vise frem fordi det er så sårbart. Alle ønsker å fremstå som vellykket. Hvis vi som behandlere fremstår som usårbare, vil pasienten vegre seg for å vise sin sårbarhet, som de føler bekrefter at de er tapere. Skam er en følelse som sier at jeg er feil, mens skyld sier at jeg har gjort feil. 


\section{De andres blikk}

Han forteller at mange av pasientene trenger hjelp til å frigjøre seg fra andres blikk ellermer presist - det de tror er andres blikk. Særlig de ressurssterke som har valgt seg en referansegruppe høyt på rangstigen, sliter med å være bra nok ut fra egne forventninger og ser ikke at de fungerer langt over gjennomsnittet. Mange såkalt vellykkede leger føler seg mindreverdige privat.

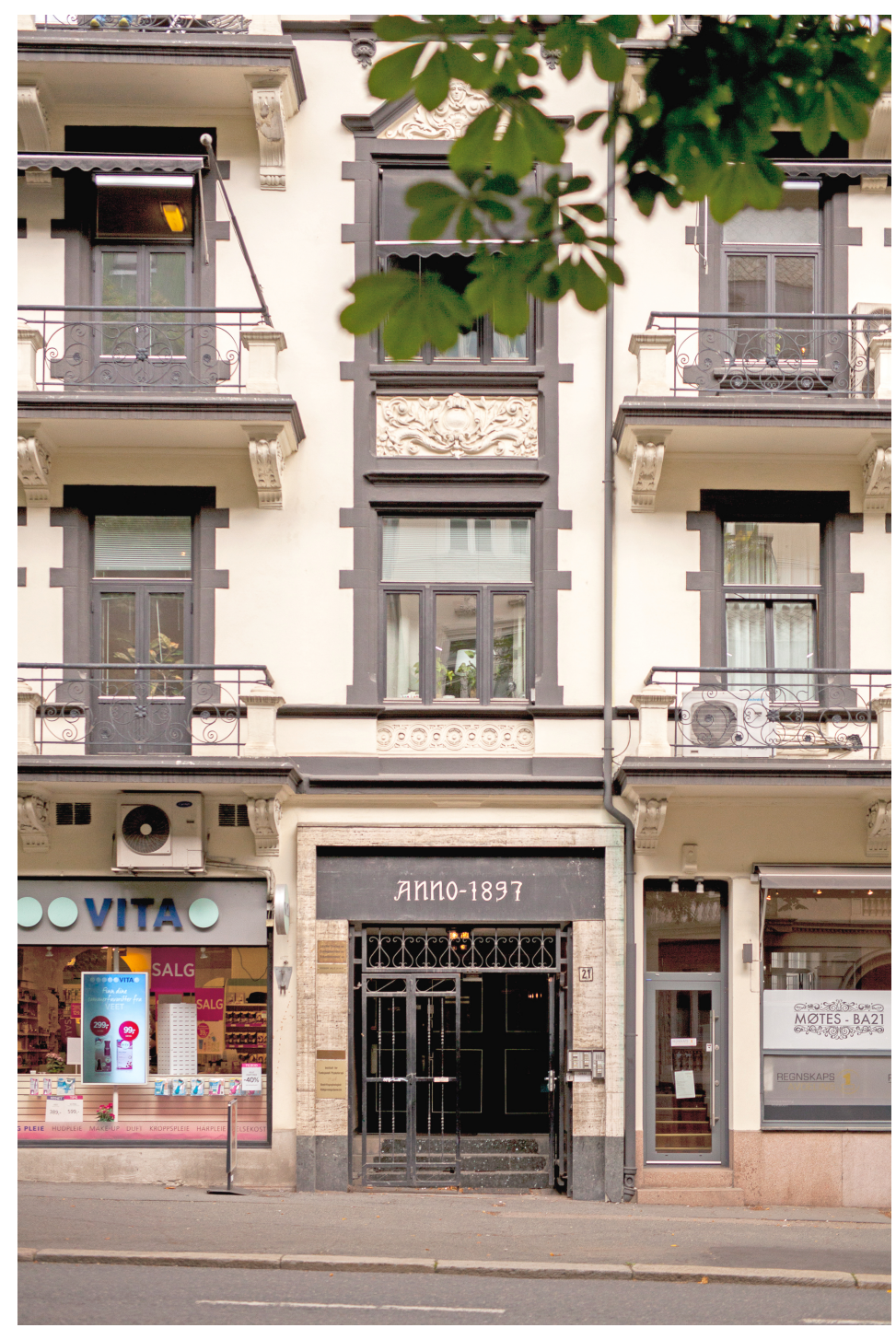

- Vi sammenligner oss alltid med en valgt referansegruppe. Flytter du inn i et finere strøk eller skaffer deg høy utdanning, blir ikke livet lettere. Da har du fått en ny referansegruppe som hever dine forventninger til det å være vellykket. Her ligger noe av skammens kjerne.

Tormod Huseby forteller at han hadde en interessant opplevelse på kurset Legeforeningen arrangerer for leger som runder 60 år. - Vi ble utfordret på følgende spørsmål: «Hvorfor er du verdifull?» Mange i denne gruppen av respekterte fagpersoner klarte ikke å svare, men ingen stilte heller spørsmålet om de faktisk var verdifulle.

\section{Klassereisen}

Tormod Huseby tar imot sine pasienter i en bygård med stort oppussingspotensial i Bygdøy allé i Oslo. Han har mange ressurssterke pasienter fra hovedstadseliten.

- Jeg merker ofte godt forskjellen på de få jeg får henvist fra andre områder av landet. Deres utfordringer har gjerne andre uttrykksformer. Siden jeg er arbeiderklassegutt og nå omgås likesinnede akademikere, det vil si har erfaring fra ulike sosiale lag, har jeg et fortrinn jeg ofte drar veksler på.

En student med en medieprofilert og intellektuell far hadde hele livet følt at han kun ble 
verdsatt av faren når han presterte intellektuelt i samtaler. Han hadde lest om Tormods far i boken hans og misunte ham en slik far. Tormod fortalte denne pasienten om sitt barndomshjem, der det var tre bøker i bokhyllen. Ingen forventet at han skulle få gode karakterer. En gang han fortalte sin far om noe fra Amazonas, spurte faren om det var i England.

- Jeg husker godt hvor rart det var for meg å oppdage at min far ikke engang visste hvor Amazonas lå. Selv hadde jeg reist på denne elven i tre dager. For meg har det å utforske den ytre verden, ikke bare den indre, vært en lidenskap. Far var fornøyd med den relativt lille verdenen han levde i. Her var det verken prestasjonsangst eller urealiserte forventninger til livet. Hvorfor skulle han ha behov for å vite hvor Amazonas lå?

\section{Smilet}

Tormod Huseby er tre ganger blitt invitert til samtaler på Litteraturhuset i Oslo om sin siste bok. Temaet fenger. En kveld sto maskene vi bærer i sentrum.

- Det siste som faller, er smilet, sier han. - Faller smilet, dukker tristheten frem. Vi hører det også når pasienten sier: «Jeg burde ikke sitte her og sutre. Alt ligger til rette for at jeg skal kunne ha et godt liv.» Da er det min jobb å få dem til å vedkjenne seg tristheten, å finne kjernen bak den og anerkjenne dens opprinnelse og smerte, sier han.

- Smilet er hensiktsmessig som sosialt lim, men kan også fungere som kamuflasje. Mange, kanskje særlig unge kvinner, kommer inn til første time med et stort smil og beretter så om slitsomme depresjoner. Selv om de er flotte på alle vis, føler de seg ikke bra nok fordi det er noen små feil i lakken. Som oftest handler det om at de ikke er vellykket på alle områder. Da tenker jeg det er magemålet som er for stort. Tidligere professor i sosialmedisin Per Fugelli har skrevet om viktigheten av å velge et bra-nok-punkt som svarer til realitetene.

- Boken din handler om viktigheten av å være seg selv. For egen del tenker jeg det kan være lurt å holde litt igjen. Enkelte sider ved oss er det kanskje vel så greit å holde for seg selv for å få det sosiale samspillet til å gli bedre.

- Ja, hvis vi tenker evolusjonært, er det fundamentalt å oppføre seg slik at man ikke blir utstøtt. En pasient sa til meg en gang at å være seg selv er sosialt selvmord. Problemet oppstår når vi mister kontakten med vårt opprinnelige jeg og det å spille falskt går på autorefleks. Frykten for ensomheten kan skape så falske mennesker at de ikke lenger vet hvem de er.

\section{Ensomhet}

- Ensomhet er kanskje vår tids siste tabu. I dag virker det som det er mer stuerent å være deprimert. Hvorfor er det så vanskelig å innrømme at man er ensom?

- Vi er redde for å være tapere, å være feil. Psykoanalytikeren Erich Fromm skrev at menneskets skjebne er ensomhet. For å tåle ensomhet må vi ha det godt med oss selv. Det er der positiv psykologi feiler: Vi kan ikke tenke positivt hele tiden, det passer bare for psykopater og døde mennesker. Vi mennesker må lære oss å tåle å stå i det negative og i vår tristhet og tore å vise det. Det er først når du erkjenner at du føler deg avvist at du kan tåle å leve med din ensomhet. Alle blir jo avvist, du kan ikke forvente at alle skal like deg. Du liker jo ikke alle andre, så hvorfor skal alle like deg? Her tror jeg det også kan være nyttig å spørre pasientene hvorfor det er så viktig å bli likt, å få dem til å tenke over om slike tanker er nyttige. Kanskje kan dette spørsmålet vise dem hvor mye bedre man kan ha det med lavere forventninger. 


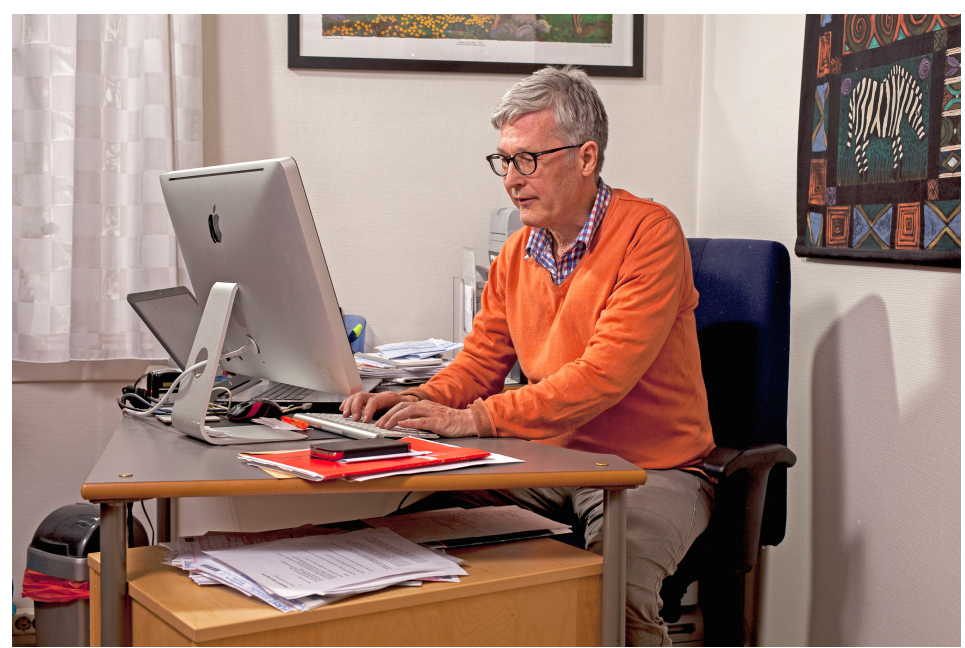

- Noen hevder at de deprimerte ser på seg selv som mer mislykket enn de faktisk er. Kan det være omvendt - at en som ikke sliter med depresjon, egentlig er for optimistisk på egne vegne? At vi til vanlig tror litt for godt om oss selv, mens den deprimerte ser seg selv i et klarere lys?

- Her må vi skille mellom lettere depresjon og dyp depresjon, der pasienten opplever seg selv som verdiløs. Det er en alvorlig misoppfatning av sin egenverdi. Men jeg tror det er riktig at vi kanskje overser negative sider ved oss selv når vi har det bra. Kanskje er det nødvendig for å ha det bra med seg selv? sier han.

- Fortrengning i riktige doser er mentalt sunt. Men i vår tid kan jo livsløgnen bli så omfattende at vi mister oss selv. Det kan være verre enn å være deprimert. Narsissister lever på en stor livsløgn. Når de lånte fjærene er borte, er alt tomt - fordi de aldri har tatt innover seg sine svakere sider. Evolusjonært må vi være kameleoner for å bli godtatt av flokken, men risikoen er underliggende tomhet. Det er som om vi ikke lever. Den som er sterk nok til å vise sin sårbarhet, åpner for at andre tør vise sin. Sammen blir de da mer ekte og mindre ensomme. I terapirommet kan vi som terapeuter legge til rette for ekte møter der pasienten kan la masken falle og vise sin sårbarhet.

\section{Slitet med å skrive godt nok}

Tormod Huseby brukte tre år på sin siste bok. Et forlag hadde spurt ham om å skrive den, men da han leverte førsteutkastet, var tilbakemeldingen negativ. Flere omarbeidinger senere fikk han beskjed om at den røde tråden fortsatt manglet og at de kanskje måtte skrinlegge utgivelsen. Men overgangen fra skam til stolthet - og motsatt - kan være kort.

- Redaktøren hadde tillit, tålmodighet og tro på meg, slik gode foreldre og terapeuter også skal ha. Et utkast fra henne som disposisjon var det som skulle til for å få manuset på plass. Redaktøren gledet seg og kalte boken en perle.

Tormod forteller åpent om skamfølelsen han slet med i denne perioden, den var så sterk at han fikk oppblomstring av sin ulcerøse kolitt, som ikke hadde gitt symptomer på mange år.

- Kroppen er en slagmark for uløste konflikter, men det er underlig å kjenne det på sin egen kropp. Da mageplagene sto på som verst, fikk jeg attpåtil diagnosen cøliaki. Jeg fikk da interesse for koblingen mellom psykiatri og ernæring. Med probiotika og glutenfri kost skjedde det forunderlige at psoriasisen jeg hadde strevd litt med i mange år forsvant. Jeg tror selv at cøliakien var selve basisen for kolitten. Her har legestanden et forsømt fagfelt som jeg håper det blir mer kunnskap om nå som tarmens viktige rolle for helsen vår er blitt mer anerkjent. 